\title{
KNOWLEDGE REGIMES AND COMPARATIVE POLITICAL ECONOMY
}

\author{
John L. Campbell \\ Department of Sociology \\ Dartmouth College \\ and \\ International Center for Business and Politics \\ Copenhagen Business School \\ and \\ Ove K. Pedersen \\ International Center for Business and Politics \\ Copenhagen Business School
}

February 2007

Thanks go to Michael Allen, John Hall, Vivien Schmidt, Wolfgang Streeck, and the editors for comments, and to Scott Schonfeld for research assistance. Address correspondence to: John Campbell, 123 Silsby Hall, Department of Sociology, Dartmouth College, Hanover, New Hampshire 03755 USA, (John.L.Campbell@Dartmouth.Edu),or Ove K. Pedersen, International Center for Business and Politics, Copenhagen Business School, Steen Blichers Vej 22, 2000 Frederiksberg, Denmark (op.cbp@cbs.dk). 


\section{KNOWLEDGE REGIMES AND COMPARATIVE POLITICAL ECONOMY}

Comparative political economy has been dominated since the 1970s by two waves of research. The first one examined how different types of policy-making regimes affect policy making and, in turn, national economic competitiveness (e.g., Katzenstein 1978). The second one studied how different types of production regimes affect national competitiveness (e.g., Hall and Soskice 2001). Absent from all of this is much discussion about knowledge regimes. Knowledge regimes are sets of actors, organizations, and institutions that produce and disseminate policy ideas that affect how policy-making and production regimes are organized and operate in the first place. Knowledge regimes are important because they contribute data, research, theories, policy recommendations, and other ideas that influence public policy and, thus, national economic competitiveness (Baab 2001; Campbell 1998; Pedersen 2006).

It is surprising that such a blind spot exists. Since the early 1990s a rich literature has emerged on how ideas, broadly construed, affect policymaking (Campbell 2002). Some proponents of the production regime and policy-making regime approaches have contributed to this literature (e.g., Hall 1993; Katzenstein 1996). It is ironic, then, that they have not more systematically connected their work on ideas with their work on policy-making and production regimes. This paper does so by showing how knowledge regimes vary across different types of political economies.

We proceed, first, by reviewing the research on ideas and knowledge regimes in order to make the point that virtually no one has tried to situate an analysis of knowledge regimes within an analysis of policy-making and production regimes. Second, we compare the most important factors distinguishing between basic types of policy-making and production regimes. We do so in order to construct a fourfold typology of political economies. Third, for each of these political economic types we examine representative countries to see how their knowledge regimes are organized. The principle countries in question are the United States, Britain, Germany, and France, although we briefly discuss a few others as well. Fourth, we summarize this empirical discussion by hypothesizing the ideal-typical knowledge regimes that are likely associated with our four types of political economies.

We argue that liberal market economies with decentralized, open states (the United States) tend to have market-oriented knowledge regimes that are highly competitive and often partisan and adversarial. Liberal market economies with centralized, closed states (Britain) also tend to have competitive knowledge regimes, but the level of partisan competition is tempered politically by public funding for knowledge producers in civil society and by the state's own inhouse analytic capacities. Coordinated market economies with decentralized, open states (Germany) tend to have relatively more consensus-oriented knowledge regimes as a result of having political economies with strong associational and corporatist institutional arrangements, parliamentary systems that often produce coalition governments, and much public funding for knowledge producers. Finally, coordinated market economies with centralized, closed states (France) tend to have statist-technocratic knowledge regimes where much policy-relevant knowledge is produced in-house by the state. Of course, competition and conflict over ideas exist within all types of knowledge regimes. Our point is that the manner in which this is 
handled, and whether it produces winners and losers or compromise and consensus, depends on the institutional configuration of the political economy in question.

This paper breaks new ground. To our knowledge, it is the first one to combine insights from the diverse literatures on production regimes, policy-making regimes, and ideas to better understand how policy-relevant knowledge is created. In particular, we are not aware of any other studies that analyze how production and policy-making regimes together affect the organization and functioning of knowledge regimes. This is our central concern.

Three caveats are in order. First, our argument is preliminary, based only on secondary literatures, and, therefore, requires elaboration through future research. Second, we focus on how different political economic institutions affect how knowledge regimes are organized and operate. That is, we focus on the knowledge production process. We are not concerned in this paper with either the content of that knowledge per se or the impact that it may have on policy makers, or with how these ideas may cause changes in political economic institutions. Although obviously important, these are issues that cannot be addressed adequately without detailed historical case studies, which are well beyond the scope of this paper. Third, while we accept that ideas often matter, we are not assuming that once an idea is created it always has an impact on policy making. We recognize that ideas get selected, modified, or ignored depending on constellations of power.

\section{Research On Ideas and Knowledge Regimes}

Three literatures point to the importance of knowledge regimes. First is an extensive literature on how ideas affect the policy-making process (Campbell 2002). It focuses on how different types of ideas, such as policy programs, intellectual paradigms, public sentiments, and frames affect the policy-making process. However, much of this work focuses on how the structure of different types of ideas constrains policy making. Missing is much discussion of the actors, organizations, and institutions that affect the creation, framing, and transmission of these ideas. That is, the literature privileges ideational structure over agency and, thus, does not clearly specify some of the most important actors and mechanisms whereby knowledge affects states and economies (Campbell 2004, chap. 4; Yee 1996). Furthermore, with only rare exceptions (e.g., Fourcade-Gourinchas and Babb 2002), few researchers have examined how the operation and impact of the knowledge regimes that produce these ideas in the first place vary cross-nationally.

A second much smaller group of studies takes agency more seriously and investigates how knowledge regimes are organized, how they create policy ideas, what the mechanisms are by which these ideas are disseminated to policy makers, and how all of this varies among countries. Some studies focus on only knowledge regimes in a single country (e.g., Hall 1993). Some studies examine how different policy ideas were used politically to shape policy making, but pay relatively little attention to how the organization and operation of the knowledge regimes that produced these ideas were determined by surrounding political-economic institutions (e.g., Blyth 2002). Some studies show how policy ideas diffused across countries and the conditions under which these ideas took root or not. But, again, they ignore how these ideas were produced in the 
first place by different types of knowledge regimes (e.g., Hall 1989). Finally, some studies analyze how knowledge regimes were organized and operated in different countries. But these efforts either explore countries belonging to the same type of production regime, thus limiting the possibilities for drawing comparisons across production regimes (e.g., Furner and Supple 1990; Nielsen and Pedersen 1991), or they focus on knowledge regimes during the late nineteenth and early twentieth centuries, an era during which states, economies, and presumably knowledge regimes were much different than they are today (e.g., Rueschemeyer and Skocpol 1996).

Finally, a third literature focuses on think tanks, often defined as non-profit organizations, formally independent from government, and engaged in the analysis of public policy issues. Think tanks attempt to influence policy in many ways, such as by providing expert analysis or lobbying. They often display a high level of scientific expertise (Stone 1996a). This literature tends to be highly descriptive. Much of it is based on analyses of only single countries, often the United States or Britain. And, most important, while some of it seeks to explain cross-national variation in the think tank environment by referring to the institutional features of policy-making regimes, it virtually ignores how the character of production regimes affects knowledge regimes (e.g., McGann and Weaver 2000; Stone et al. 1998).

Overall, then, all three of these literatures point toward, but in most cases do not systematically develop, an analysis of knowledge regimes along the lines we have proposed. Nonetheless, we will draw on this work where appropriate to develop our arguments.

\section{Production and Policy-Making Regimes}

The first step in our analysis is to differentiate among important types of production and policy-making regimes. Our purpose in reviewing these well-known differences is to enable us to identify in the next section of the paper four ideal types of political economies and then to discuss what we believe are representative examples of knowledge regimes associated with each one.

Comparative political economists often distinguish between two types of production regimes (e.g., Hall and Soskice 2001). Liberal market economies, such as the United States and Britain, structure economic activity primarily through markets and corporate hierarchies where corporate managers respond primarily to price signals and make strategic decisions without much consultation with other organizations in their environment. Coordinated market economies, such as Germany and France, structure economic activity more through non-market relationships, such as informal networks, formal corporatist bargaining, associations, and various forms of state intervention and regulation. In some cases, corporate managers consult regularly with other stakeholders-that is, those with a vested interest in the corporation, such as employees, customers, suppliers, and shareholders-and tend to coordinate their decision making with them. In other cases, the state ensures that coordination occurs. Hence, the process of economic coordination and decision making in liberal market economies is driven by market-based competition whereas in coordinated market economies it is also driven by institutionally-based cooperation of various sorts. In other words, decision making in coordinated market economies 
tends to be multilateral and often more consensus oriented than it is in liberal market economies where it tends to be unilateral, typically dominated by corporate managers, and less consensus oriented.

The distinction between liberal and coordinated market economies has been criticized for ignoring important differences among countries, especially within the coordinated category (Amable 2003; Crouch 2005). For instance, France relies heavily on the state as a means of nonmarket coordination whereas Germany relies heavily on corporatist bargaining. Even proponents of the liberal-coordinated dichotomy have acknowledged recently the significance of these differences (e.g., Hall and Gingerich 2004).

Regarding policy-making regimes, researchers often distinguish between two institutional types of states (e.g., Katzenstein 1978). In centralized and closed states policy making is located in a few policy-making arenas that tend to be insulated from the external influences of civil society. Policy-making authority is vested primarily in the national government. And the electoral victor often controls both the executive and legislative branches of the government. Moreover, these states often have an extensive, well-developed, permanent, and professional civil service extending far up the bureaucracy. As a result, few bureaucratic layers are subject to removal after elections. In decentralized and open states policy making is much less insulated from external influences, policy-making authority is often shared or delegated to lower levels of government, as is typical in federalist systems, and the permanent civil service is much less extensive.

\section{Political Economies and Knowledge Regimes}

How do different types of political economies affect knowledge regimes? In this section we identify four types of political economies based on the distinctions reviewed in the previous section. For each type we will examine how the knowledge regimes of certain countries are organized and operate. We argue that the institutional configuration of a country's knowledge regime reflects and is largely determined by its surrounding political-economic institutions.

There are several types of knowledge producing organizations in most knowledge regimes. We focus on four that have received the most attention in the think tank literature. First are academic-style scholarly research units, sometimes referred to as universities without students. These are staffed with scholars, professional researchers, and analysts, often with joint university appointments. They are often dependent on public funding. They produce expert research monographs and journal articles much like those found in academia. They also tend to be politically and ideologically non-partisan. Second are advocacy research units. They tend to be privately funded and are politically and ideologically partisan. They are less concerned with conducting scholarly research than with packaging and disseminating the research of others in brief policy papers and through the media in order to influence the ideological climate, public debate, and public policy. Third are party research units. These are closely associated with political parties and provide a source of expert advice and analysis for party members. Sometimes they are actually housed within the party apparatus itself. Fourth are state research 
$\underline{\text { units }}$ either directly affiliated with specific government departments and ministries or created on an ad hoc basis to advise government on a specific matter. Unlike the first three, these are largely apart from civil society. ${ }^{1}$

\section{Liberal Market Economy/Decentralized, Open State}

The United States is typically characterized as a liberal market economy with a decentralized, open state. Business associations are not nearly as important in organizing the interests of business in the United States as they are in most European countries. Labor unions are also very weak by comparison. Corporatism is virtually unheard of. And cartels and Japanese or German style business networks are largely absent.

Insofar as the political landscape is concerned, when compared to most other advanced capitalist democracies the two major political parties are rather weak and poorly disciplined because elections are based on winner-take-all rules and candidates are funded primarily through private contributions. Furthermore, political power is decentralized as a result of constitutional federalism, there is a clear separation of powers between legislative and executive branches of government, and these branches are frequently controlled by different parties. There are dozens of congressional committees affording outsiders access to the policy-making process. Finally, the permanent civil service is not nearly as well developed or extensive as it is in many other countries. When a new government is elected, many high-level personnel in cabinet bureaucracies and administrative agencies are replaced with new political appointees in what amounts to a political spoils system.

The U.S. knowledge regime reflects these political-economic institutions. There are well over 1,000 research units in the United States today and over 100 inside Washington D.C. alone (Gellner 1995). There is a long history of scholarly research units. The first were established in the early twentieth century and received most of their financial support from philanthropic organizations and occasionally corporations. Examples include the Russell Sage Foundation, the Hoover Institution, and later the Brookings Institution. Because their finances were secured by generous endowments they did not have to cater to the partisan pressures of donors. Their goal was to improve and rationalize the political decision-making process-not influence the political agenda. After the Second World War, a second generation of scholarly research units like the RAND Corporation as well as university-based research institutes were set up as a result of the federal government's desire to contract out for policy research (Abelson 2004). All of this was consistent with the principles of liberal market economies, which favor private sector activity whenever possible.

Beginning in the 1970s, a generation of advocacy research units developed. These

${ }^{1}$ Some people have referred to these types of organizations as think tanks. Because there is much debate-and even confusion-about exactly what a think tank is (e.g., Stone 2004; Rich 2004), we avoid this language entirely. 
included the conservative Heritage Foundation, Cato Institute, and Manhattan Institute, and a few liberal organizations, such as the Institute for Policy Studies. They often resembled interest groups insofar as they pressured decision makers to implement policies compatible with their ideological beliefs and those shared by their generous benefactors (Abelson 1998; Rich in this volume).

There are no party research units per se. But there are some state research units, such as the General Accounting Office, the Congressional Budget Office (CBO), the Congressional Research Service (CRS), and the Office of Management and Budget. There is also the President's Council of Economic Advisors, which appoints experts, often from universities, to conduct various policy analytic activities. Many congressional committees also have research staffs. And most cabinet-level departments have assistant secretaries directing professional research and evaluation units. The capacity for research that some of these organizations have is greater than most research units in civil society and has grown over the years. Notably, the CBO and CRS have staffs of about 200 and 900 people, respectively. Given the constitutionally mandated separation of powers in the United States, and the fragmented nature of the legislative and executive branches, it is not surprising that there are so many research units inside the state. However, this facilitates much competition between branches and agencies and, therefore, their research units. Again, this has created opportunities for state research units to supply data, analysis, technical advice, and political argument to players in these political contests. Some observers have argued that the proliferation of state research units has diminished the relative influence of other types of research units in the policy-making process (Smith 1989). Nevertheless, compared to most European countries, the U.S. knowledge regime is dominated much more by scholarly and advocacy research units than by party and state research units (Abelson 1992; Gellner 1995).

Political-economic institutions led to the development of this sort of knowledge regime in several ways. First, the phenomenal growth of scholarly and advocacy research units has much to do with the fact that tax law makes it easy to establish a tax-exempt, non-profit organization. Corporate financing is also readily available. So private resources are available to finance research units to a much greater extent than in many other countries. This is consistent with a liberal market economy insofar as much support is given to corporate initiative and private sector volunteerism.

Second, the decentralized, open nature of the state afforded scholarly and advocacy research units plenty of opportunities to reach policy makers and their staffs if they wanted to do so. For instance, the proliferation of new government programs and bureaucracies and the related demands of the civil rights and anti-war movements catalyzed the emergence of liberal scholarly research units during the 1960s. In turn, this led to a counter mobilization by conservatives who then formed or expanded the capacities of their own scholarly and advocacy research units, often with corporate financing (Abelson 1992; Fischer 1991; Ricci 1993).

Third, comparatively speaking, the government is dominated by temporary political appointees rather than professional career bureaucrats. This also encourages dependency on 
outsiders for intelligence, analysis, and policy advice (Abelson 1998; Coleman 1991; Gellner 1995; James 1993). Indeed, the initial growth of research units in civil society after the Second World War was driven in part by a demand among policy makers for policy expertise, particularly in foreign policy.

Finally, political parties are weak and have not established significant in-house policy research capacities of their own. Moreover, given the undisciplined nature of political parties, American politicians are less likely to toe the party line than politicians in other countries. Hence, they are more inclined to seek policy advice and expertise from scholarly and advocacy research units (Abelson 2004, 2000, 1998).

It follows that the United States is much more a competitive market place for ideas than most other countries. Indeed, advocacy research units, but to an increasing extent also the more scholarly research units, engage strategically in that competition by trying to attract the attention of the media and influence public opinion in ways that are comparatively unique (Abelson 1992, 2004; Feulner 2000). Today, the partisan competitive marketing of ideas has gained ground while scholarly detachment has lost ground (Gellner 1995). In terms of its large number of scholarly and advocacy research units, the generous funding and staffing that they often enjoy, the increasingly partisan nature of their activities, and the intensely competitive nature of policyrelevant knowledge production and dissemination, the U.S. knowledge regime is rather exceptional compared to those in other countries.

\section{Liberal Market Economy/Centralized, Closed State}

Britain is a liberal market economy with a centralized, closed state. Despite fleeting experiments with corporatism during the 1960s and 1970s, British business associations are not especially central to the coordination of economic activity and state regulation is fairly limited. There has been some state-ownership in a few infrastructure sectors, but considerably less so since privatization during the 1980s under Margaret Thatcher's conservative government. Labor is better organized than in the United States, but not nearly as well organized as in most continental European countries. So, markets and corporate hierarchies are the key mechanisms of economic governance.

Regarding the state, there are two major political parties competing for power in a winner-take-all electoral system, as there are in the United States. But in Britain, the parties are well-disciplined so members of parliament generally toe the party line. And as is true in most parliamentary systems, the party in power typically controls both the legislature and executive branches. Hence, the government can more or less do what it wants without significant opposition. Moreover, Britain has a highly professional, extensive, and permanent civil service which remains despite changes in the ruling party. Finally, in contrast to U.S. federalism, state power is centralized at the national level. Policy-making authority is vested in the Prime Minister's office, the cabinet, and the bureaucracy; it is not diffused into parliamentary committees; and there are fewer points of access to policy makers. 
Britain has a much smaller field of research units than the United States. There are some scholarly research units. These were first set up during the inter-war period, but more were founded immediately after the Second World War. They emerged in response to political necessities and the inadequacies of contemporary research facilities. Many are publicly funded. Notably, the Royal Institute of International Affairs and the National Institute of Economic and Social Research were established for these purposes and produce a variety of scholarly documents and reports on a wide range of policy-relevant topics (Day 2000; Denham and Garnett 1998; James 1993).

A few advocacy research units have also been around for a long time. The Fabian Society, for example, was established in 1884 and eventually became loosely affiliated with the Labor Party (Day 2000; Denham and Garnett 2004). And the Mont Pelerin Society was established in the 1940s to advance conservative, free market ideas (Desai 1994). That said, beginning in the 1970s, and in response to the perceived failures of Keynesian policies, more advocacy research units emerged with strong conservative orientations, such as the Center for Policy Studies and the Adam Smith Institute, which was established in 1974 by Sir Keith Joseph and Margaret Thatcher (Denham and Garnett 1998, 2004; Stone 1996b). Moreover, financial institutions in London began to develop in-house research and analytic capacities that were important in developing and disseminating monetarist and other neoliberal ideas (Hall 1993). In the late 1980s and 1990s leading figures from academia, business, and the unions set up alternatives, such as the Institute for Public Policy Research (IPPR) and Demos, to reverse the intellectual dominance of the right (Denham and Garnett 1999; Stone 1996b).

All of these advocacy research units had close ties to either the Conservative or Labor parties, although they were not established by the parties per se and, therefore, should not be considered party research units. However partisan they may be, the major conservative advocacy research units make serious, thoughtful, well-researched contributions, although they also sometimes recycle ideas from elsewhere and use the media to their advantage strategically (Desai 1994; Gaffney 1991). The same is true for IPPR. In any case, advocacy research units now represent a considerably larger proportion of all civil society research units in Britain than in the coordinated market economies of Europe (Day 2000, pp. 128-29). But compared to the United States, British advocacy research units are relatively rare, have smaller staffs, and have less funding (Denham and Garrnet 1998, 1996; James 1993). Over all, there is a dearth of research units in British civil society.

Britain has a considerable number of state research units. For instance, in 1970 Edward Heath established the Central Policy Review Staff (CPRS), which was comprised of civil servants and provided his government with in-house specialist advice across departments (Denham and Garnett 1999). There are also various planning and research units in most government departments. These are staffed by civil servants and enjoy a degree of independence and autonomy from policy makers and administrators. There are also state research units staffed mainly with outside appointees, notably the Prime Minister's policy unit. The civil service also has semi-detached inspectorates that provide it with independent professional opinion on issues like social services or pollution. And there are public advisory bodies, such as the Social 
Security Advisory Committee, set up by government but acting and advising independently. Many of these are formed on an ad hoc basis (James 1993).

Why has Britain developed this sort of knowledge regime? In particular, why are there relatively few research units in civil society, especially when compared to the United States? First, most British research units in civil society are established under law as charities and, thus, are required to be educational and non-partisan, which also prevents them from lobbying and engaging in similar political activities. And because the tax system is less accommodating for charitable giving than it is in the United States-perhaps because the British state has greater capacity for providing services that might otherwise be provided by charities-there are fewer foundations to support these research units in Britain in the first place (James 1993; Stone 1996b; 1996a, chap 3). That said, as in other liberal market economies, corporations are another source of financial support for advocacy and scholarly research units (Fieschi and Gaffney 1998).

Second, the British civil service is more extensive, reaching up to the permanent bureaucratic counterpart of a minister. It also has more internal policy-making capacity, is protective of its dominant position as provider of policy advice, and regards itself as an intellectual elite capable of handling any problem (Coleman 1991; Stone 1996a, chap. 3). Indeed, outside experts are rarely invited to policy discussions because civil service culture assumes that administrative officials are capable of transmitting any specialist material themselves to policy makers, and because the constitutional principle of neutrality within Whitehall requires civil servants to keep their distance from external policy institutes (Coleman 1991; Stone 1996b; 2000).

Third, the opportunities for research units in civil society, especially advocacy research units, is limited by the fact that the centralization and insulation of political decision making creates only occasional windows of opportunity for them to have input-windows that are controlled significantly by the Prime Minister. Thus, in 1983 Thatcher abolished Heath's CPRS, but was quite open to the Adam Smith Institute. In contrast, John Major shut out virtually all civil society research units. And the relationship between Tony Blair's government and advocacy research units seems to have fallen somewhere in between (Denham and Garnett 2004). As such, the state research units seem to be more influential on a permanent basis. And those in civil society, especially the advocacy research units, sit precariously on the edge of the political process using publicity to affect public opinion and government thinking as best they can (Gaffney 1991).

Overall, then, Britain has a smaller field of research units in civil society than the United States because funding possibilities and points of access to the state are more limited and uncertain. However, as noted earlier, advocacy research units have increased significantly since the 1970s. In this regard, both Britain and the United States have competitive market places for ideas. This is not surprising insofar as they both also have traditions of very acrimonious politics due to their winner-take-all electoral systems, which, for instance, encourage advocacy research units to pursue high public profiles (Thunert 2000). But in Britain partisan ideational competition is mollified to a greater degree than in the United States by public funding for 
knowledge producers in civil society, fewer channels of political access, and by the state's own in-house analytic capacities.

It is worth mentioning that Australia is another liberal market economy with a relatively centralized, closed state whose knowledge regime resembles Britain's. There are very few research units in civil society in Australia and most of them emerged since the 1970s, are small, and operate on a financial shoe string. The nation's tax structure makes it very difficult to establish philanthropic organizations. Business has stepped forward in some cases to provide funding, but only when it is assured that the business perspective will be represented. Moreover, Australian political parties are strong, well disciplined, and have considerable in-house policy research expertise. Hence, they are closed to external policy research and advice. Insofar as the state is concerned, as in Britain, there are few conduits into government for the exchange of information and personnel. And so the efforts of Australian research units in civil society are often trumped by those of state research units whose analytic strengths and resources are far superior (Stone 1998).

\section{Coordinated Market Economy/Decentralized, Open State}

Germany represents a good example of a coordinated market economy with a relatively decentralized, open state (Katzenstein 1987). It is a country whose economic actors are organized through corporatist institutions; where consensus building is held in high regard among these actors; and where networks of firms, suppliers, and banks typically work together to coordinate economic activity. Because Germany has a federalist political system, much policymaking authority devolves to the regional-level Länder governments, which is one reason why the national government lacks the same sort of extensive permanent civil service found, for instance, in Britain or France. Moreover, Germany's system of proportional representation tends to ensure further that politics is based on consensus building often absent in winner-take-all systems like the United States and Britain. This is also facilitated by six major, well-disciplined political parties.

Germany's knowledge regime has relatively few state research units providing in-house expertise and advice. Instead, it is dominated by over 100 scholarly research units, including those affiliated with universities, churches, and other non-profit organizations. Altogether, they constitute over half of all the research units in Germany. The Max Planck Institute for the Study of Societies and the Social Science Center Berlin (WZB) are notable examples (Thunert 2000, 2004). Many are also quite large, were created by the government after the war, and receive about half their funding from the federal government and half from the Länder governments. In fact about 75 percent of all German research units receive public funding. This financial arrangement reflects Germany's federal structure as well as the government's desire to encourage competing views on economic policy and economic development (Thunert 2000, 2004, p. 71). Chief among the scholarly research units are the so-called Big Six non-partisan economic and social research institutes that were created after the Second World War and funded largely by the federal and Länder governments. Policy makers rely on them heavily, particularly when political consensus is fragile. They are considered to be the most important and influential organizations 
in the field. In general, policy makers depend more on scholarly research units than other types (Day 2000; Gellner 1998).

There are also research units closely associated with the major labor organizations, business associations, and political parties. The Confederation of German Employers Associations, The Federation of German Industry, and the German Federation of Trade Unions have long had their own research units. And each of the major political parties has its own research unit or political foundation, as they are often called, which are more prominent and better funded than their peers in most other countries in part because state funds support them too (Thunert 2000, 2004, pp. 77-78). For instance, the Social Democratic Party sponsors the Friedrich Ebert Stiftung. Except for their party affiliations, the political foundations resemble the full-service scholarly research units found in the United States, such as the Brookings Institution or the American Enterprise Institute. The influence of labor or business research units, of course, varies depending on the party or coalition in power (Day 2000; Gellner 1998).

The existence of many well-funded scholarly and party-based research units has created a situation where there is little space available for the sort of independent, privately funded advocacy research units that are found more commonly in the United States and Britain. Although their numbers have been growing since 1980, they still constitute only about 30-40 percent of all German research units. They have relatively little political influence (Gellner 1998; Weilemann 2000). In fact, most German research units are proud of their scholarly reputations, research profiles, and the scientific soundness of their work, which they do not want to jeopardize by excessive partisan advocacy (Thunert 2000).

Germany's knowledge regime reflects the strong institutional tendencies within the political economy for corporatist interest mediation, interlocking federalism, negotiation among the political parties, and for consensus building in general. Indeed, until the late 1970s the development of German research units was almost entirely driven by demands of the state, corporatist organizations close to the state, and the political parties. First, given the fact that labor and business peak associations are expected to contribute to consensus-oriented policy discussions, and that coalition governments are often in place, the large unions, business associations, and parties have recognized the benefits of having their own reliable sources of policy analysis and ideas and so established their own research units (Thunert 2000).

Second, the state places a higher premium on objective, scientific knowledge than in many other countries. As mentioned above, the importance placed on producing high quality knowledge and policy advice is important to virtually all German research units, but especially the scholarly ones. Everyone remembers how the Nazis and then, in East Germany, the communists manipulated scientific knowledge for their own political purposes. Nobody wants to repeat those mistakes. Hence, the state subsidizes many scholarly research institutes to ensure that their work is of the highest quality. And beginning in the 1990s most publicly funded scholarly research units have been reviewed by the Science Council (Wissenschaftsrat)-a joint federal-Länder advisory board that evaluates these research units on standard academic criteria, such as that used typically to evaluate academic departments and institutions of basic research. 
Heavy reliance on state funding brings with it certain obligations that have limited the degree to which research units can engage in policy advising, partisanship, or ideational marketing rather than basic research-obligations that have limited the development of advocacy research units (Thunert 2004).

Third, the absence of many privately funded advocacy research units is also due to the fact that the permanent career civil service, which is perhaps more extensive than in other decentralized, open states, has its own internal policy-making capacities and is traditionally wary of relying too heavily on external advice-particularly that which it cannot oversee. Although Germany's federal structure provides more possible access points to policymakers than do most parliamentary democracies of the Westminster type, this attitude has also helped mitigate the proliferation of advocacy research units (Thunert 2000).

There is a tendency for more consensus-oriented knowledge production in Germany than in many other types of political economies-a tradition that seems to reflect the traditions of corporatist bargaining and coalition government. Many well-established research units in civil society are members of institutionalized consulting networks. Notably, the Big Six work together and seek consensus on policy analysis and economic projections. Twice a year they produce the so-called Common Report-a joint analysis of the government's short- and mediumterm performance. This is an analytic exercise-not one designed to offer policy recommendations per se. Such recommendations are left to other research institutes, such as the Stiftung für Wissenschaft und Politik. Thke intention is for all six institutes to concur on a joint conclusion, although recently this has not always happened (Atkins 2006; Benoit 2006; Thunert 2004).

Of course, German research units compete intensely for funding, prestige, and the attention of policy makers as they do elsewhere. They often represent different political or ideological positions and, as a result, do not always agree on things, as illustrated by the recent dissent among the Big Six. But because they tend to adopt a very scholarly approach where standards of research are high, and because they understand the consensus-oriented nature of German policy making, their policy recommendations are likely to be tempered to a degree often absent in liberal market economies like the United States and even Britain. Indeed, policy makers typically solicit input from a mixture of advisors from different backgrounds and a variety of party and scholarly research units, including those affiliated with unions and business (Thunert 2000). Furthermore, another reason why the major research units are likely to moderate their tone is because most of their funding comes from the public sector, which is typically run by coalition governments (Weilemann 2000, p. 173).

Since the Second World War the Netherlands has resembled Germany in the sense that it is a political economy based in large part on corporatist negotiation and coalition governments that strive for consensus building. It also lacks the sort of extensive civil service seen, for instance, in centralized, closed states like Britain and France that have considerable in-house policy research and analytic capacities. All of this spills over into the Dutch knowledge regime. 
Research units play an important role in policy making in part because, beginning in the 1960 s, the state apparatus began growing rapidly, policy making could no longer be run from a single political center, and so the government moved to develop external social science expertise for policy making. First, American-style advocacy research units are rare. Second, each of the twelve political parties developed an adjunct party research unit (Day 2000). Third, and more important, there is a group of publically funded scholarly research units, which provide independent, external advice to the government.

An important example is the Social Economic Council, which is composed of representatives from labor unions, employer organizations, and crown appointees. Another is the Netherlands Scientific Council for Government Policy, which is considered the country's research unit par excellence and is composed of 11 members appointed by the queen on recommendation of the prime minister. It consists typically of economists, sociologists, legal scholars, international relations specialists, and natural scientists-most of whom are university professors-but also occasionally people from large corporations. Care is taken to ensure that it is not politically partisan or ideologically biased. It focuses on socioeconomic policy and government organizations, and it has about 40 scientific and administrative staff. It provides policy advice on many subjects; has independence vis-a-vis the government in terms of setting its agenda and doing its work; publishes reports free of government interference; and seems to have influence on the policy-making process. Yet it is linked to the government in terms of its budget and appointment process.

The point is that the Netherlands' coalition-based, parliamentary, multi-party system, coupled with a state lacking an extensive technocracy and in-house analytic capacities, created space for truly independent, non-partisan, scholarly research units. And the country's proclivity for corporatist negotiation and political coalition building is reflected in the organization of its knowledge regime (Baehr 1986; Day 2000; Mentzel 1999).

\section{Coordinated Market Economy/Centralized, Closed State}

France is an example of a coordinated market economy with a centralized, closed state. There is much less corporatism in France than in Germany, but since the Second World War the state engaged in much indicative planning based on formal consultations among labor, business, the Ministry of Finance, and other relevant ministries, and often facilitated by the Commissariat du Plan. So economic governance in France is rather statist relative to the other countries discussed here. Furthermore, France has a long history of state-owned enterprise in critical infrastructure sectors. However, the French state's capacity to influence the economy is also considerable because it is very centralized. Policy-making authority is vested largely in the national government; the executive branch tends to hold sway over the legislature; and policymaking is closed and insulated formally from many outside pressure groups. Moreover, policymaking tends to be technocratic due to the fact that the state has an extensive, permanent, and well-trained civil service. Finally, there are several well-disciplined political parties and an electoral system of proportional representation, which often results in coalition governments. 
Much of France's policy research and analysis is conducted by state research units. In addition to the Commissariat du Plan, which conducts much research and analysis itself, most ministries have similar analytic capacities (Desmoulins 2000). Furthermore, each ministry has its own cabinet, an ad hoc group of experts arranged around a minister offering him analysis and policy advice. The cabinets complement and often rival the traditional ministerial bureaucracy (Fieschi and Gaffney 2004). By law each minister has the right to appoint a number of advisors to her cabinet. Most of them are civil servants coming from the École Normale d'Administration (ENA), where they are trained to become loyal, non-partisan, technocratic servants of the state regardless of the particular government in power. The cabinets also include outsiders, notably expert intellectuals from the leading universities. The cabinets have become key lynch pins connecting political ideas and their application. They have great influence upon agenda setting and policy elaboration. They were instrumental, for instance, in helping the Mitterrand government develop new policies after it abandoned its pre-1981 socialist agenda (Desmouolins 2000, p. 154; Fieschi and Gaffney 1998; Gaffney 1991).

France's knowledge regime also includes an elaborate network of scholarly research units, many of which belong to one of two principal umbrella bodies: the Center National de la Recherche Scientifique (CNRS) and the Institut National de Statistiques et d'Études Economiques (INSEE). CNRS runs about 1,500 research laboratories and research centers around the country, but only a small number of these do policy research (Desmoulins 2000, p. 144). INSEE generates social, economic, and political data and analysis and the Institut National d'Études Demographique (INED) provides demographic data and analysis. Their researchers and managers are drawn mostly from the Grandes Écoles-the elite national universities. Most of the scholarly research units under these umbrella organizations are much smaller in terms of staff and budget than those in the countries discussed earlier. None are comparable in terms of multidisciplinary competence to the most prestigious scholarly research units in the United States, like Brookings. Most are linked to a particular state administrative organization, receive financing from either it or another state agency, hire civil servants on a part-time basis, and are affiliated with academic institutions. Most also have state representatives sitting on their boards of directors. Many are reviewed annually by the Conseil d'Etat (state council) to ensure that they are performing a public service function (Day 2000; Desmoulins 2000; Fieschi and Gaffney 2004).

The political parties have research units, but these are relatively insignificant. That said, so-called political clubs emerge occasionally that represent a kind of distant cousin to traditional party research units, but more closely resemble advocacy research units. Political clubs are groups of experts, scholars, and other political advisors. They often coalesce around a particular political figure, usually someone who is out of power but seeking high political office. For instance, Club 89 formed around Jacques Chirac, and Démocratie 2000 and Clysthène formed around Jacques Delors. Such clubs often arise when the party to whom their political figure is affiliated is viewed as performing badly, so the relationship between the clubs and parties is often contentious. When the government's Algerian policies were questioned during the 1950s and 1960s dozens of political clubs were created that fostered the new left movement in France. Often political clubs dissolve as soon as the crisis that produced them has passed. As a result, 
political clubs are a kind of transitory hybrid. They resemble party research units insofar as they are loosely affiliated with a party, or at least with an individual or movement that is affiliated with a party. But they are also like advocacy research units to the extent that they are identified mostly through their ideological or political commitments, seek to impact public debate, and only occasionally do a bit of research. They often act more like ideological lobbies than scholarly research units (Desmoulins 2000, p. 154; Fieschi and Gaffney 2004).

There are some full-fledged advocacy research units. Notably, the French new right established two very well known research units: the Groupement de Recherche et d'Étude sur la Civilisation Européenne (GRECE), founded in 1968, and the Club de l'Horloge, founded in 1974. Both sought to influence politics through research and debate and carve out a political discursive space comparable to what the new left had done (Fieschi and Gaffney 2004).

Although advocacy research units have been comparatively unimportant in France, they have been on the rise since the mid-1990s. Given the intricacies of French electoral politics, this has been a time during which a left-wing government and prime minister has cohabited with a Gaullist president. Both president and prime minister have sought to broaden their powers vis-avis each other and the balance of power between the two heads of the executive has been quite unstable. In this intensely competitive political environment, advocacy research units have been relied upon more than usual as sources of information, advice, and policy proposals.

Nevertheless, advocacy research units in France are neither large nor long-lived. And they tend not to be affiliated with a particular political party but rather gather together on a temporary basis around single issues (Desmoulins 2000, pp. 149-50).

France's political-economic institutions are largely responsible for the state-centered organization of its knowledge regime. First, the French civil service culture does not provide many opportunities for research units in civil society to participate in policy making. Indeed, most policy makers turn only rarely to these research units for expertise and advice because they already have their own in-house sources of experts in various disciplines within the civil service (Desmoulins 2000, p. 149).

Second, given the highly centralized, closed nature of the state, parliament is not a regular client for independent public policy expertise. This is much different from the situation in the United States where dozens of congressional committees and subcommittees often seek outside policy expertise and, therefore, provide many channels of access for research units to engage policy makers. So, with few exceptions, party research units, including political clubs, and traditional advocacy research units tend to be of little use to French policy makers. They may affect public debate, but it is not clear that they affect policy making per se (Desmoulins 2000; Fieschi and Gaffney 1998).

Third, the reluctance to turn to research units in civil society in France also stems from a long-standing distrust of the market in French politics-a distrust that has meant that the French state is seen as a protector of the republic (Desmoulins 2000, p. 145-46). Similarly, political parties have been historically mistrusted of excessive partisanship, political divisiveness, and of being disruptive to the republic, which further hobbles the capacity of party research units to 
exercise much influence (Fieschi and Gaffney 2004).

Fourth, the French state plays an extensive role in protecting the welfare of its citizens so there is no well-developed philanthropic sector. The absence of private philanthropy as well as a lack of much interest among corporations for providing financial support also contributes to the paucity of many research units in civil society (Desmoulins 2000; Fieschi and Gaffney 2004). This also contributes to the generally small scale of most of these research units. And it is one reason why these organizations often have to scramble to make ends meet financially by pursuing not only state subsidies, but also contracts from both public and private actors (Desmoulins 2000).

We have shown that France's knowledge regime is dominated by state research units as well as scholarly research units closely tied to the state, such as those associated with CNRS. But it is also dominated by a class of people with very similar intellectual and social backgrounds-many of whom are drawn from the prestigious ENA and Institut des Études Politiques. Hence, the French knowledge regime is not only rather statist and technocratic in comparison to other countries, but also more elitist. And this intellectual elite, which is heavily concentrated in Paris, provides much informal advice to policy makers. Indeed, France has a long tradition whereby intellectuals influenced policy makers through personal connections so it is only as a last resort that these experts participate in research units to influence policy (Desmoulins 2000, p. 153).

Some features of the French knowledge regime can be found in other countries with coordinated market economies and centralized, closed states. For instance, post-Franco Spain inherited a centralized state bureaucracy, a weakly organized civil society, a tendency for much state coordination of the economy, and a lingering distrust by the state of civil society organizations. Moreover, the legal framework since Franco's demise in 1975 has been slow to change so it has not provided extensive fiscal incentives for the formation of non-profit organizations. And private sector organizations have been more concerned with maintaining their special prerogatives than in promoting their broader policy interests. Hence, Spanish research units are rare, numbering only about 100 . Of these, the largest minority are state research units. About 40 percent are also scholarly research units. They rely heavily on public financing and tend not to aggressively market their findings or develop a particular political profile, preferring instead to cultivate an image of objectivity and neutrality (Freres et al. 2000).

Similarly, Japanese policy-making has been conducted historically behind closed doors in a centralized, closed state, albeit in consultation with leaders of large corporations and trade associations. It has also been carried out by governments dominated by one party throughout most of the post-Second World War era. Indeed, policy making is largely controlled by government ministries in a technocratic fashion similar to that in France. Neither the law in general nor the tax code in particular allow for an independent, non-governmental, non-profit sector. Furthermore, Japanese intellectuals and the media engage in much self-censorship when commenting on government policies. As a result, research units in civil society are rare. There are a few public non-profit research organizations, which in practice are simply extensions of the 
ministries and, therefore, resemble state research units. Foremost among them is the National Institute for Research Advancement, which was established in 1974 and that provides policy makers with relevant and unbiased research information. There are also a few for-profit scholarly research units, such as the Mitsubishi Research Institute, financed by industry or banks. But the bulk of policy research is conducted by state research units (Ueno 1998).

\section{Toward An Ideal-Typical Account of Knowledge Regimes}

Based on the country descriptions presented above, we now draw some tentative conclusions about the nature of knowledge regimes in different types of political economies. The discussion is summarized in Table 1, which presents four ideal-type knowledge regimes corresponding to the four types of political economies we have just discussed. Our intent here is to develop some initial propositions to guide future research.

\section{Table 1 about here}

We suspect that in liberal market economies with decentralized, open states knowledge regimes will be characterized by many privately funded scholarly and advocacy research units, some state research units, and no party research units to speak of. This market-oriented knowledge regime represents an intensely competitive market place of ideas. It is marked by partisan and adversarial contests among knowledge producers trying to influence both public opinion and policy makers. Of the four types of knowledge regimes, this one is probably the most competitive and the most heavily reliant on private financing, both corporate and philanthropic, although there are certainly plenty of government contacts and grants. The state research units also compete against one another and against research units in civil society for the attention of policy makers.

In contrast, we hypothesize that knowledge regimes in liberal market economies with centralized, closed states will have fewer scholarly and advocacy research units. These will be supported by a mixture of public and private funds. It will also have a much more substantial set of state research units. There will be few significant party research units. So, compared to the liberal market economies with decentralized, open states, the mixture of types of research units will be a bit more balanced. And like its decentralized, open state counterpart, this knowledge regime will be a partisan, adversarial, and competitive market place for ideas. However, the importance of the competitive market place for ideas will be tempered by the significant role that state research units play, particularly within the well-established civil service. As a result, we call this type the politically-tempered knowledge regime.

Insofar as coordinated market economies are concerned, we suggest that those with decentralized, open states will have a moderately sized set of research units in civil society, dominated primarily by scholarly research units rather than advocacy research units. These organizations will be heavily dependent on public funding. There will also be an important array of party research units and a reasonable number of state research units. The comparative absence of advocacy research units is indicative of the fact that this knowledge regime is less oriented to 
competitive, partisan, and adversarial competition, and more oriented toward the production of knowledge for a consensus-oriented policy process. This consensus-oriented knowledge regime is consistent with the surrounding corporatist institutions and system of proportional representation in electoral politics, which puts a premium on consensus building and moderation in policy making. Whereas ideational competition is tempered by the state in liberal market economies with centralized, closed states, ideational competition is tempered in coordinated market economies with decentralized, open states by a generally accepted and institutionally supported concern with compromise.

Finally, we come to the statist-technocratic knowledge regimes found in coordinated market economies with centralized, closed states. We anticipate that these will have few advocacy or party research units. There will be more publicly funded scholarly research units and state research units of various sorts. Economic coordination depends far more on the state in this type of political economy than in the rest, which is why the production of policy-relevant knowledge will also be left largely to the state. Again, the absence of advocacy research units signals that knowledge production in these countries is relatively non-partisan. But in contrast to coordinated market economies with decentralized, open states, where knowledge regimes exhibit tendencies toward ideational consensus building, coordinated market economies with centralized, closed states will likely have knowledge regimes that are highly technocratic in orientation. Ideational competition that might occur otherwise will be tempered by technocratic fiat.

\section{Conclusions}

This paper represents an attempt to map the topography of knowledge regimes in different types of political economies. Our intent has been to specify the various organizational actors and institutional mechanisms by which policy-relevant ideas are generated in different political-economic types. Attention to these sorts of actors and mechanisms has been lacking in much of the literature on how ideas affect the policy-making process. As such, the paper represents an improvement on the general literature on ideas and policy making reviewed earlier.

The paper also reunites two literatures in comparative political economy-the work on policy-making and production regimes-to suggest how different institutional forms of political economies affect how knowledge regimes are organized and operate. In this regard, it begins to rectify the curious separation in the work of some comparative political economists where, on the one hand, they discuss the importance of ideas and, on the other hand, they examine how policymaking and production regimes operate, but without much attention to the role of ideas and knowledge regimes.

We recognize the limitations of typologies, particularly those based on simple dichotomous distinctions. Notably, the literature on production regimes, which provided us with the concepts of liberal and coordinated market economies, has been criticized for being overly simplistic and neglecting the proliferation of hybrid forms (Campbell and Pedersen 2007; Crouch 2005). As a result, there may be important differences in production, policy-making, and, therefore, knowledge regimes among countries that fall into any of the four political economic 
types we have discussed. Hybrid forms are likely.

This paper advances the literature on think tanks upon which we have relied heavily. First, much of this literature only examines the relationship between research units and policymaking regimes, not production regimes. Yet we have shown that both policy and production regimes shape knowledge regimes.

Second, the think tank literature takes a rather narrow view of what policy-relevant knowledge producing organizations are. It focuses primarily on advocacy and scholarly research units. Much less attention is paid to either state research units or research units associated with political parties. This may be because the bulk of the literature focuses on the United States and Britain, two liberal market economies where advocacy and scholarly research units are comparatively prominent. By expanding the range of countries under observation to include coordinated market economies, we have found that other types of research units are particularly important in certain types of political economies.

Third, much of the literature on think tanks dwells on the organization of research units (e.g., the number of research units operating, their funding sources, their staffing levels, etc.). Much less attention is paid to the process by which knowledge is produced and disseminated to policy makers. We have suggested that this process may vary tremendously, ranging from highly competitive, adversarial, and politically partisan, to comparatively consensual and non-partisan, to rather technocratic. The process depends on the organization of the knowledge regime, which depends in turn on the organization of the production and policy-making regimes with which it is associated. Much more needs to be learned about these processes-particularly because they may have significant effects on the content of that knowledge and the impact it has on policy makers.

We have said very little about content and impact. But one thing is striking. Since the late 1970s, among the countries discussed here the most radical neoliberal policy advice emerged in two liberal market economies, the United States and Britain, where privately funded advocacy research units enjoyed influential positions in the knowledge regime, and knowledge production and dissemination was a comparatively contested and competitive process with fairly clear winners and losers. Other types of knowledge regimes with different processes did not produce such radical advice. This suggests that different processes may affect the content of the knowledge produced. Our hunch is that coordinated market economies tend to produce policy knowledge that favors comparatively incremental policy reform whereas liberal market economies tend to produce policy knowledge that favors more radical policy reform. Why? Because knowledge regimes in coordinated market economies are more consensus or technocratically oriented and, therefore, cautious while in liberal market economies they are more partisan, adversarial, and acrimonious, and, therefore, prone to more extreme policy recommendations. This, of course, also raises the issue of what impact knowledge regimes actually have, or not, on policy makers-a methodologically vexing question that scholars have only begun to address (e.g., Abelson 2002).

Two final thoughts are in order. We recognize that adding an historical dimension to our 
analysis would probably confound our knowledge regime typology to a degree insofar as realworld knowledge regimes often evolve dynamically in ways that make it difficult to fit them neatly into any one ideal type. For example, the rise of advocacy research units was an important shift in many of our countries and may signal a shift toward more competitively oriented knowledge regimes.

We also recognize that specifying particular policy areas might confound our fitting of cases to political-economic typologies. For instance, if we examined the knowledge regime associated specifically with U.S. defense policy, it might be difficult to fit this case into the liberal market economy/decentralized, open state category because defense policy-making is considerably less public and more insulated within the Department of Defense and a few congressional committees. And historically defense policy makers have relied heavily on only a few scholarly research units operating on government contracts like the RAND Corporation. But if we looked at the knowledge regime associated with economic or trade policy, then the fit might be better. The point is that the more closely one specifies the policy area, the more likely it is that there will be variation within countries in terms of how their political economies and, therefore, their knowledge regimes are organized and operate. 


\section{References}

Abelson, Donald E. 2004. "The Business of Ideas: The Think Tank Industry in the United States." Pp. 215-31 in Think Tank Traditions, edited by Diane Stone and Andrew Denham. Manchester: Manchester University Press.

. 2002. Do Think Tanks Matter? Montreal: McGill-Queen's University Press.

. 2000. "Do Think Tanks Matter? Opportunities, Constraints and Incentives for Think

Tanks in Canada and the United States." Global Society 14(2)13-36.

. 1998. "Think Tanks in the United States." Pp. 107-27 in Think Tanks Across Nations:

A Comparative Perspective, edited by Diane Stone, Andrew Denham and Mark Garnett.

Manchester: Manchester University Press.

. 1992. "A New Channel of Influence: American Think Tanks and the News Media."

Queen's Quarterly 99(4)849-72.

Amable, Bruno. 2003. The Diversity of Modern Capitalism. Oxford: Oxford University Press.

Atkins, Ralph. 2006. "Germany's Confidence Highest for Fifteen Years." The Financial Times, March 29, p. 1.

Babb, Sarah. 2001. Managing Mexico. Princeton: Princeton University Press.

Baehr, Peter R. 1986. “Think Tanks-Who Needs Them?” Futures (June)389-400.

Benoit, Bertrand. 2006. "Germany Set on Tax Rise Despite Criticism.” The Financial Times, March 29, p. 3.

Blyth, Mark M. 2002. Great Transformations: The Rise and Decline of Embedded Liberalism. New York: Cambridge University Press.

Campbell, John L. 2004. Institutional Change and Globalization. Princeton: Princeton University Press.

. 2002. "Ideas, Politics, and Public Policy." Annual Review of Sociology 38:21-38.

. 1998. "Institutional Analysis and the Role of Ideas in Political Economy." Theory and Society 27:377-409.

Campbell, John L. and Ove K. Pedersen. 2007. "The Varieties of Capitalism and Hybrid Success: Denmark in the Global Economy." Comparative Political Studies. 40(2)307-32. 
Coleman, David A. 1991. "Policy Research-Who Needs It?" Governance: An International Journal of Policy and Administration 4(4)420-55.

Crouch, Colin. 2005. Capitalist Diversity and Change. New York: Oxford University Press.

Day, Alan J. 2000. "Think Tanks in Western Europe.” Pp. 103-39 in Think Tanks and Civil Societies, edited by James G. McGann and R. Kent Weaver. New York: Transaction Publishers.

Denham, Andrew and Mark Garnett. 2004. "A 'Hollowed Out' Tradition? British Think Tanks in the Twenty-First Century." Pp. 232-46 in Think Tank Traditions, edited by Diane Stone and Andrew Denham. Manchester: Manchester University Press.

. 1999. "Influence Without responsibility? Think Tanks in Britain." Parliamentary Affairs 52(1)46-57.

. 1998. "Think Tanks, British Politics, and 'Climate Opinion'." Pp. 21-37 in Think Tanks Across Nations: A Comparative Perspective, edited by Diane Stone, Andrew Denham and Mark Garnett. Manchester: Manchester University Press.

. 1996. "The Nature and Impact of Think Tanks in Contemporary Britain.” Pp. 43-61 in Ideas and Think Tanks in Contemporary Britain, edited by Michael Kandian and Anthony Seldon. London: Frank Cass.

Desai, Radhika. 1994. "Second-Hand Dealers in Ideas: Think Tanks and Thatcherite Hegemony." New Left Review 203:27-64.

Desmoulins, Lucile. 2000. "French Public Policy Research Institutes and Their Political Impact as Another Illustration of French Exceptionalism.” Pp. 139-69 in Think Tanks and Civil Societies, edited by James G. McGann and R. Kent Weaver. New York: Transaction Publishers.

Feulner, Edwin. 2000. "The Heritage Foundation." Pp. 67-85 in Think Tanks and Civil Societies, edited by James G. McGann and R. Kent Weaver. Transaction Publishers.

Fieschi, Catherine and John Gaffney. 2004. "French Think Tanks in Comparative Perspective." Pp. 105-20 in Think Tank Traditions, edited by Diane Stone and Andrew Denham. Manchester: Manchester University Press.

. 1998. "French Think Tanks in Comparative Perspective." Pp. $42-59$ in Think Tanks

Across Nations: A Comparative Perspective, edited by Diane Stone, Andrew Denham and Mark Garnett. Manchester: Manchester University Press.

Fischer, Frank. 1991. “American Think Tanks: Policy Elites and the Politicization of Expertise.” Governance: An International Journal of Policy and Administration 4(3)332-53. 
Fourcade-Gourinchas, Marion and Sarah Babb. 2002. "The Rebirth of the Liberal Creed: Paths to Neoliberalism in Four Countries." American Journal of Sociology 108:533-79.

Freres, Christian, Maria Joao Seabra, and Maria do Rosário de Moraes. 2000. "Think Tanks in Spain and Portugal: Searching for Relevance." Pp. 187-221 in Think Tanks and Civil Societies, edited by James G. McGann and R. Kent Weaver. New York: Transaction Publishers.

Furner, Mary O. and Barry Supple, editors. 1990. The State of Economic Knowledge. New York: Cambridge University Press.

Gaffney, John. 1991. "The Political Think-Tanks in the UK and the Ministerial Cabinets in France." West European Politics 14(11)1-17.

Gellner, Winand. 1998. "Think Tanks in Germany." Pp. 82-107 in Think Tanks Across Nations: A Comparative Perspective, edited by Diane Stone, Andrew Denham and Mark Garnett. Manchester: Manchester University Press.

. 1995. "The Politics of Policy 'Political Think Tanks' and Their Markets in the U.S. Institutional Environment.” Presidential Studies Quarterly 25(3)497-

Hall, Peter. 1993. "Policy Paradigms, Social Learning, and the State: The Case of Economic Policymaking in Britain." Comparative Politics 25(3):275-96.

Press.

, ed. 1989. The Political Power of Economic Ideas. Princeton: Princeton University

Hall, Peter A. And Daniel Gingerich. 2004. "Varieties of Capitalism and Institutional Complementarities in the Macroeconomy: An Empirical Analysis." Discussion Paper 04/5. Cologne Germany: Max Planck Institute for the Study of Societies. Available at www.mpi-fgkoeln.mpg.de.

Hall, Peter A. and David Soskice. 2001. “An Introduction to Varieties of Capitalism.” Pp. 1-70 in Varieties of Capitalism, edited by Peter A. Hall and David Soskice. New York: Oxford University Press.

James, Simon. 1993. "The Idea Brokers: The Impact of Think Tanks on British Government." Public Administration 71(Winter)491-506.

Katzenstein, Peter J. 1996. The Culture of National Security. New York: Columbia University Press.

1987. Policy and Politics in West Germany. Philadelphia: Temple University Press.

, ed. 1978. Between Power and Plenty. Madison: University of Wisconsin Press. 
McGann, James G. and R. Kent Weaver, editors. 2000. Think Tanks and Civil Societies. New York: Transaction Publishers.

Mentzel, Maarten. 1999. "Think Tanks, Policy-Making, and a Dutch Advisory Council." Science and Public Policy 26(3)171-78.

Nielsen, Klaus and Ove K. Pedersen. 1991. "From the Mixed Economy to the Negotiated Economy: The Scandinavian Countries." Pp. 145-65 in Morality, Rationality, and Efficiency, edited by Richard Coughlin. Armonk, NY: M.E. Sharpe.

Pedersen, Ove K. 2006. "Denmark: An Ongoing Experiment." Pp. 453-70 in National Identity and the Varieties of Capitalism: The Danish Experience, edited by John L. Campbell, John H. Hall, and Ove K. Pedersen. Montreal: McGill-Queen’s University Press.

Ricci, David. 1993. The Transformation of American Politics. New Haven: Yale University Press.

Rich, Andrew. 2004. Think Tanks, Public Policy, and the Politics of Expertise. New York: Cambridge University Press.

Rueschemeyer, Dietrich and Theda Skocpol, editors. 1996. States, Social Knowledge, and the Origins of Modern Social Policies. Princeton: Princeton University Press.

Smith, James. 1989. "Think Tanks and the Politics of Ideas." Pp. 175-94 in The Spread of Economic Ideas, edited by David Colander and A.W. Coats. New York: Cambridge University Press.

Stone, Diane. 2004. "Introduction: Think Tanks, Policy Advice and Governance.” Pp. 1-18 in Think Tank Traditions, edited by Diane Stone and Andrew Denham. Manchester: Manchester University Press.

. 2000. "Non-Governmental Policy Transfer: The Strategies of Independent Policy Institutes." Governance: An International Journal of Policy and Administration 13(1)45-62.

. 1998. "The Development and Discourse of Australian Think Tanks." Pp. 145-66 in Think Tanks Across Nations: A Comparative Perspective, edited by Diane Stone, Andrew Denham and Mark Garnett. Manchester: Manchester University Press.

. 1996a. Capturing the Political Imagination: Think Tanks and the Policy Process.

London: Frank Cass.

. 1996b. "From the Margins of Politics: The Influence of Think Tanks in Britain." West European Politics 19(4)675-92. 
Stone, Diane, Andrew Denham and Mark Garnett, editors. 1998. Think Tanks Across Nations: A Comparative Perspective. Manchester: Manchester University Press.

Thunert, Martin. 2004. “Think Tanks in Germany." Pp. 71-88 in Think Tank Traditions, edited by Diane Stone and Andrew Denham. Manchester: Manchester University Press. . 2000. "Players Beyond Borders? German Think Tanks as Catalysts of Internationalization." Global Society 24(2)191-211.

Ueno, Makiko. 1998. “Think Tanks in Japan: Towards a More Democratic Society.” Pp. 188202 in Think Tanks Across Nations: A Comparative Perspective, edited by Diane Stone, Andrew Denham and Mark Garnett. Manchester: Manchester University Press.

Weilemann, Peter R. 2000. "Experiences of a Multidimensional Think Tank: The KonradAdenauer-Stiftung." Pp. 169-86 in Think Tanks and Civil Societies, edited by James G. McGann and R. Kent Weaver. New York: Transaction Publishers.

Yee, Albert S. 1996. "The Causal Effects of Ideas on Policies." International Organization 50(1):69-108. 
Table 1. Typology of Knowledge Regimes

\begin{tabular}{|c|c|c|}
\hline & Liberal Market Economy & Coordinated Market Economy \\
\hline \multirow{4}{*}{$\begin{array}{l}\text { Decentralized, } \\
\text { Open State }\end{array}$} & Market-Oriented Knowledge Regime & Consensus-Oriented Knowledge Regime \\
\hline & $\begin{array}{l}\text { Large, privately funded research unit sector } \\
\text { in civil society }\end{array}$ & $\begin{array}{l}\text { Moderate, publicly funded research unit sector } \\
\text { in civil society }\end{array}$ \\
\hline & $\begin{array}{l}\text { Scholarly and advocacy research units } \\
\text { dominate }\end{array}$ & $\begin{array}{l}\text { Scholarly, party, and state research units evenly } \\
\text { balanced }\end{array}$ \\
\hline & $\begin{array}{l}\text { Highly adversarial, partisan, and } \\
\text { competitive knowledge production process }\end{array}$ & $\begin{array}{l}\text { Consensus-oriented, relatively non-partisan } \\
\text { knowledge production process }\end{array}$ \\
\hline \multirow{4}{*}{$\begin{array}{l}\text { Centralized, } \\
\text { Closed State }\end{array}$} & Politically-Tempered Knowledge Regime & Statist-Technocratic Knowledge Regime \\
\hline & $\begin{array}{l}\text { Small, publicly \& privately funded research } \\
\text { unit sector in civil society }\end{array}$ & $\begin{array}{l}\text { Large, publicly funded research unit sector in } \\
\text { civil society }\end{array}$ \\
\hline & $\begin{array}{l}\text { Scholarly, advocacy, and state research } \\
\text { units evenly balanced }\end{array}$ & Scholarly and state research units dominate \\
\hline & $\begin{array}{l}\text { Moderately adversarial, partisan, and } \\
\text { competitive knowledge production process }\end{array}$ & $\begin{array}{l}\text { Technocratic, non-partisan knowledge } \\
\text { production process }\end{array}$ \\
\hline
\end{tabular}

